\title{
Kerry promises spectrum sale to fund science
}

Geoff Brumfiel, Washington

Democrat John Kerry, the US presidential candidate, has unveiled a strategy for investing billions of extra dollars in science and technology, with an emphasis on research in areas other than biomedicine.

The plan, released on 24 June, would raise US $\$ 30$ billion over an unspecified period of time through the auction of radio spectrum that is currently used for television broadcasts. Roughly two-thirds of the money from the sale would go towards research and development, and the rest would support incentives for ind ustrial innovation.

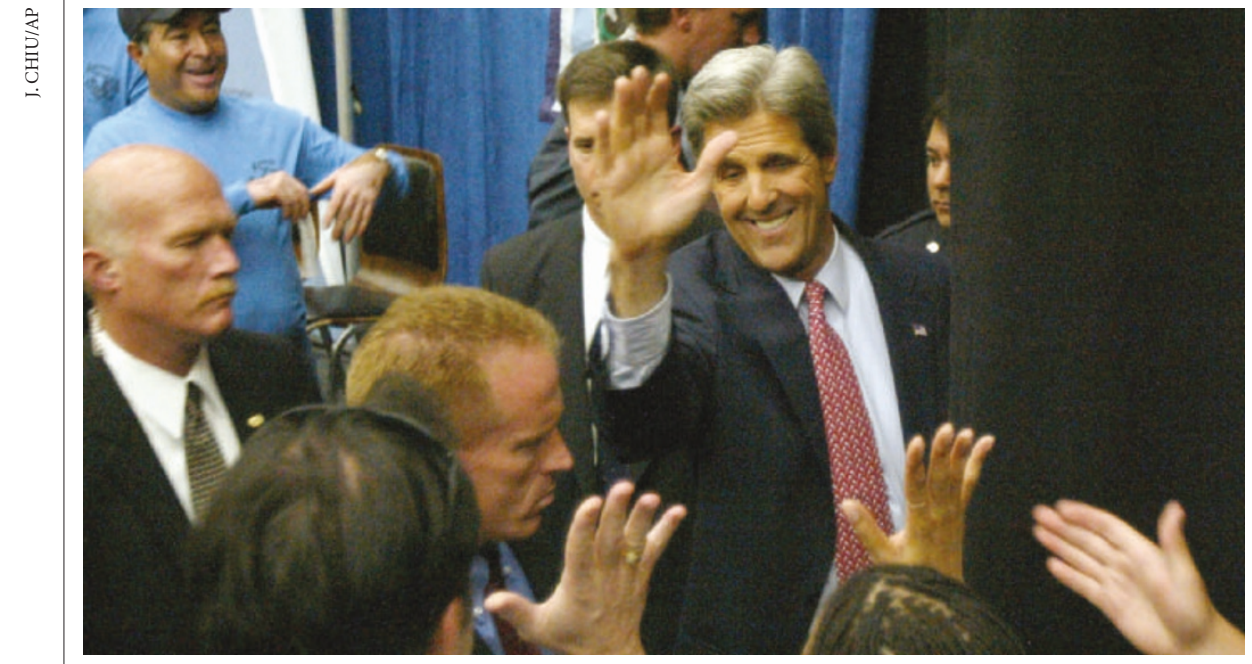

Hand outs: the source of funding for John Kerry's science plan has been ridiculed by his critics.

But critics quickly panned the proposed source of funding as a financial gimmick. "Spectrum auctions are the last refuge of budget scoundrels," says Robert Walker, a lobbyist and former Republican chairman of the House of Representatives' Committee on Science.

Kerry announced the plan in a speech at San José State University in California. "America must lead, not follow, other countries in the great discoveries that bring greater prosperity," he said.

The proposal came at the end of a week of science-oriented campaigning for the Demo-

. cratic candidate. At its start, Kerry said that, if elected, he would lift President Bush's ban on government-funded embryonic stem-cell research. He was then backed by 48 Nobel science laureates: "John Kerry will restore science to its appropriate place in government," they wrote in an open letter of endorsement.

The Kerry plan will auction radio spectrum freed for use by the conversion from analogue to digital television, says Thomas Kalil, a Kerry adviser and former assistant in President Bill Clinton's economic-policy office. The sale would produce more than $\$ 30$ billion; roughly $\$ 22$ billion would be assigned to research in areas such as nanotechnology and clean energy, and to science spending at the Department of Energy, the National Science Foundation and the Pentagon.

President Bush was advised to increase physical-sciences funding by his own scientific panel, but "has not followed through", says Michael Lubell, head of the American Physical Society's public affairs division in Washington.

Kerry's opponents say that his plan would be tough to implement and unlikely to produce dollars quickly enough. Direction of the funding would require an act of Congress, they note. And Walker points out that digital broadcasting of television is not due to be complete until the end of 2006, so no money would be available until then. Attempts to speed up the process would lead to a "huge argument with the broadcasters", Walker says.

\section{Increasing virulence of bird flu threatens mammals}

\section{Helen Pilcher, London}

An avian flu virus is mutating and

becoming more dangerous to mammals, say researchers. The discovery reinforces fears that a pandemic could yet occur in humans.

Bird flu hit the headlines in 1997 when a strain called $\mathrm{H} 5 \mathrm{~N} 1$ jumped from chickens to people, killing six people in Hong Kong. Within three days, the country's entire chicken population was slaughtered and the outbreak was controlled.

Since then, new strains of virus have emerged, killing 14 more people. As yet, no strain has been able to jump routinely from person to person. But if a more virulent strain evolves, it could trigger widespread outbreaks, potentially affecting millions of people.

Now, genetic and animal studies show the virus poses an increasing threat to mammals. Immediate action is needed to stem the virus's transmission, says Hualan Chen from Harbin Veterinary Research Institute, China, who was involved in the research.

Chen and colleagues studied 21 H5N1 flu virus samples taken from apparently healthy ducks, which act as a natural reservoir for the disease, in southern China between 1999 and 2002. The researchers inoculated groups of chickens, mice and ducks with virus samples from different years. Their results are published this week (H. Chen et al. Proc. Natl Acad. Sci. doi:10.1073/pnas.0403212101; 2004).

As expected, the ducks were immune to the virus's effects and the chickens fell sick. However, the mice also became ill, losing weight and the use of their limbs. Crucially, the severity of their illness was linked with the year from which the virus sample was taken. Viruses isolated in 2001 and 2002 made the animals more ill than those isolated earlier on.

The findings hint that some time around 2001 the virus became adept at infecting mammals. Genetic analysis of the same samples reveals that the virus's DNA changed over that time, suggesting that accumulated mutations may have contributed to the increased virulence.

Researchers are concerned that a virus that has acquired the ability to infect mice could also infect humans. "The disease could resurge at any time," warns virologist Marion Koopmans of the National Institute of Public Health and the Environment in Bilthoven, the Netherlands.

The findings highlight the need for improved surveillance to ensure that any future outbreaks are curtailed, she says. Although domestic poultry are easily culled, wild animals are more difficult to contain. "It is impossible to eradicate the natural reservoir," says Koopmans, "so we need to learn to live with it."

But birds may not be the only villains in this story. Chen believes that pigs may also play a part. In Asia, chickens and pigs are often kept in close proximity, so the virus may have shuffled back and forth between the two species, picking up mutations and becoming better at infecting mammalian hosts. 